\section{Sexual motivation and medial preoptic self-stimulation in male rats}

\begin{abstract}
NANNE E, van de POLL and HUIB van DIS
Netherlands Central Institute for Brain Research, Amsterdam, The Netherlands

Self-stimulation and sexual behavior of male rats with electrodes implanted in the medial preoptic area were studied in an experiment in which the animals were castrated and subsequently treated with testosterone propionate. The rewarding effect of an electrical stimulus in this area proved to depend upon the presense of testosterone. The results of this study provide additional evidence for the importance of the medial preoptic area in the motivational aspects of male sexual behavior.
\end{abstract}

The importance of the preoptic area for the neural regulation of sexual behavior has been shown recently by several lines of experiments.

Bilateral destruction of the medial preoptic area in the male rat abolished srxual behavior without concomitant atrophy of the gonads and the accessory sex organs (Heimer \& Larsson, 1966-67). Testosterone treatment could not restore this decline in sexual behavior. Electrical and chemical stimulation of the preoptic area can bring about high levels of sexual behavior in male rats (Fisher, 1956; Vaughan \& Fisher, 1962; van Dis \& Larsson, 1971). Hillarp et al (1954), in an earlier experiment, made electrolytic lesions in the preoptic area in rats. Some of their animals, both male and female, exhibited intense masculine copulatory responses during a short period after the operation. This short-lasting effect may suggest an electrochemical irritative stimulation of nervous structures in the vicinity of the lesion.

Preliminary experiments in this laboratory showed a strong reinforcing property of an electrical stimulus in the preoptic area of male rats, and it was easy to induce self-stimulation in this area. Olds (1958) observed that the rate of self-stimulation in some areas of the brain (septal area and lateral posterior area of the hypothalamus) decreased after castration and increased again after subsequent androgen treatment. Recently, evidence was reported for a linkage between sexual behavior and self-stimulation in the posterior hypothalamus (Caggiula \& Hoebel, 1966; Caggiula, 1970).

The present study investigates the influence of androgens upon the rewarding effect of electrical stimulation in the medial preoptic area. In order to find further evidence concerning the role of this area in the motivational aspects of sexual behavior, special attention was given the randomization test (Siegel, 1956). and ejaculations were recorded as described earlier (Larsson \& Essberg, 1962). Sexual behavior tests were discontinued when (1) no intromission occurred after a $15-\mathrm{min}$ period of observation, (2) no ejaculation occurred within $25 \mathrm{~min}$ after the first intromission, and (3) the animal ejaculated.

Each animal was tested five times weekly, i.e., two sexual behavior tests and three self-stimulation tests on alternating days. The control period consisted of nine self-stimulation and six mating tests. Thereafter, the animals were castrated under ether anesthesia. If the animals failed to have mounts in at least three consecutive mating tests, they were treated with testosterone propionate ( $150 \mathrm{micrograms/animal} /$ day) until ejaculations occurred in three RESULTS

After castration, all sexual behavior disappeared in $1 \frac{1}{2}, 3$, and $4 \frac{1 / 2}{2}$ weeks, respectively. Ten days of testosterone treatment restored the sexual behavior in all three animals.

Table 1 summarizes for each animal the self-stimulation results of: (1) the last three precastration tests, (2) the last three postcastration tests during which no mounts occurred in the parallel mating tests, and (3) the first three tests following testosterone treatment corresponding to mating tests in which the animals once again ejaculated. The response rates are given as the mean \pm SEM of the three consecutive tests.

Figure 1 shows the results for Animal No. 283, in which all self-stimulation was abolished 4 weeks after castration. The gradual decline in the self-stimulation rate closely paralleled the decline in sexual behavior. Testosterone injections reinstituted the self-stimulation several days before the sexual behavior reappeared.

Animal No. 285 showed a gradual castration but not a complete abolishment. Testosterone injections restored the behavior to the precastration level. Animal No. 287 showed only a slight but consecutive mating tests. decline of self-stimulation after

Table 1

Current and Rates of Selfstimulation (Per $15 \mathrm{Min}$ ) in the Precastration Period, the Postcastration Period, and After Testosterone Treatment*

\begin{tabular}{|c|c|c|c|c|c|c|c|}
\hline $\begin{array}{l}\text { Animal } \\
\text { Number }\end{array}$ & $\begin{array}{c}\text { Current } \\
\text { in } \\
\mu \mathrm{A}\end{array}$ & $\begin{array}{c}\text { Precas- } \\
\text { tration } \\
\text { Rate }\end{array}$ & $\begin{array}{c}\text { Postcas- } \\
\text { tration. } \\
\text { Rate }\end{array}$ & $\begin{array}{l}\text { Testos- } \\
\text { terone }\end{array}$ & $\begin{array}{c}\text { Pre } \\
\text { vs } \\
\text { Post }\end{array}$ & $\begin{array}{l}\text { Post vs } \\
\text { Testos- } \\
\text { terone }\end{array}$ & $\begin{array}{l}\text { Prevs } \\
\text { Testos- } \\
\text { terone }\end{array}$ \\
\hline 283 & 300 & $338 \pm 34$ & $0 \pm$ & $306 \pm 38$ & $<.05$ & $<.05$ & n.s. \\
\hline 285 & 175 & $532 \pm 42$ & $71 \pm 36$ & $488 \pm 158$ & $<.05$ & $<.05$ & n.s. \\
\hline 287 & 200 & $727 \pm 102$ & $403 \pm 110$ & $1028 \pm 178$ & n.s. & $<.05$ & n.s. \\
\hline
\end{tabular}

*.Wean and SEH are calculated for three cansecutile tests. Differences are tested with 


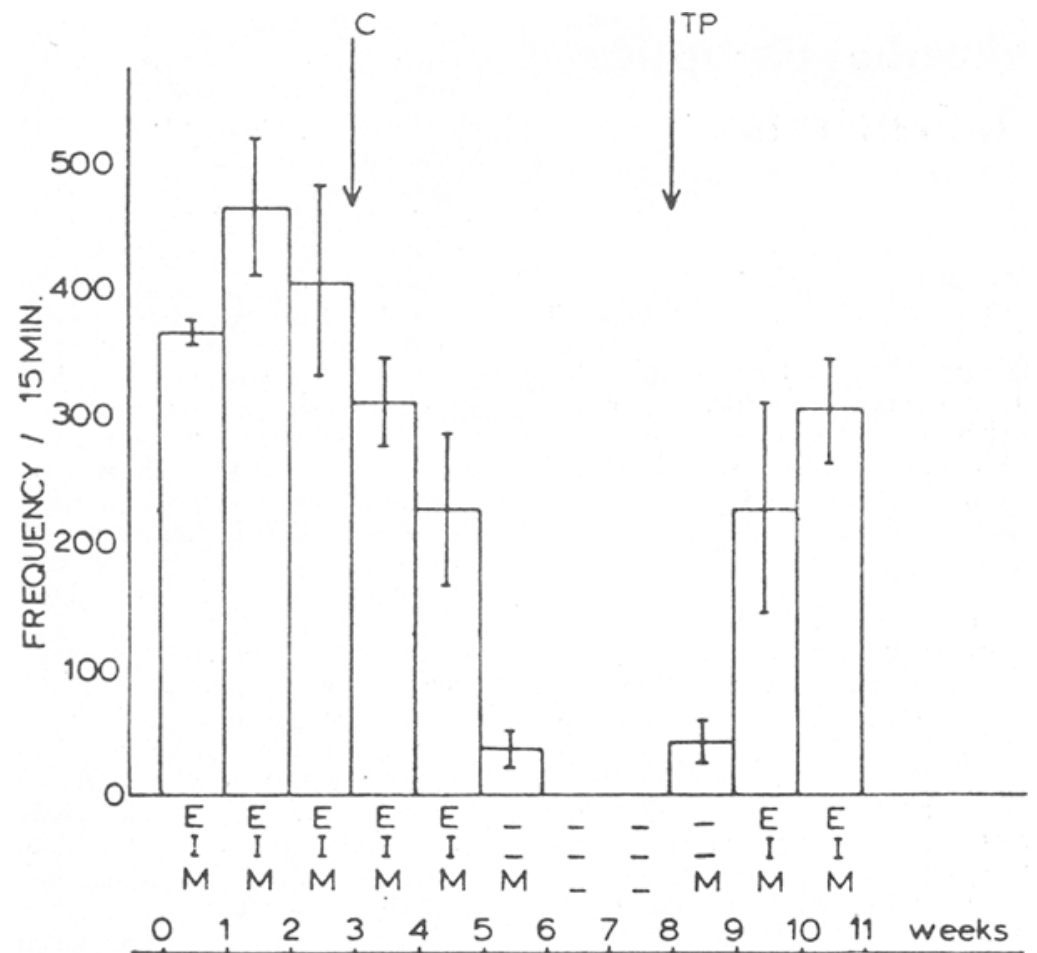

Fig. 1. Self-stimulation frequencies \pm SEM and sexual behavior of Animal No. 283. $C=$ castration; $T P=$ initiation of treatment with testosterone propionate; $M=$ mounts were recorded in the parallel mating tests; $I=$ intromissions were recorded; $\mathbf{E}=$ ejaculations were recorded.

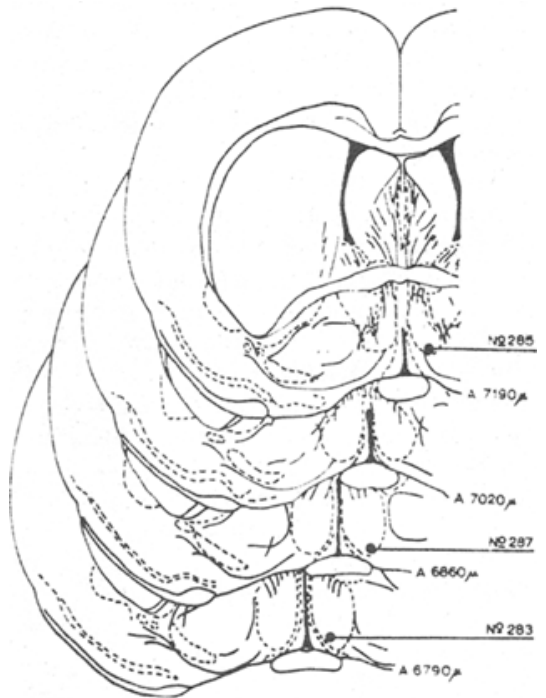

Fig. 2. Histological control of the electrode tips according to the atlas of Konig \& Klippel (1963). the animals to the experimental procedure, the question remains as to whether these might be due to small differences in the current spread within the tissue surrounding the electrodes or to other uncontrolled factors. The same holds true for other experiments (Vaughan \& Fisher, 1962; van Dis \& Larsson, 1971), in which hypersexuality was found in only $10 \%$ of the animals. The temporal relationship found in this study between sexual behavior and self-stimulation, both during the period of their decline and during that of their subsequent restoration, is an important additional argument for a relationship between the strength of sexual motivation and the rewarding effect of stimulation in the medial preoptic area. The present results increase the likelihood that the medial preoptic area is of central importance for the motivational aspects of male sexual behavior.

\section{REFERENCES}

C AGgiula, A. R. Analysis of the copulation-reward properties of posterior hypothalamic stimulation in male rats Journal of Comparative \& Physiological Psychology, 1970, 70, 399-412.

CAGGIULA, A. R., \& HOEBEL, B "Copulation-reward site" in the posterior hy pothalamus. Science, 1966, 153, 1284-1285.

FISHER, A. E. Maternal and sexual behavior induced by intracranial chemical stimulation. Science, 1956, 124, 228-229.

HEIMER, L., \& LARSSON, K. Impairment of mating behavior in male rats following lesions in the preoptic-anterior hy pothalamic continuum. Brain Research, 1966/67, 3, 248-263.

HILLARP, N. A, OLIVERCRONA, H., \& SILFVERSKIÖLD, W. Evidence for the participation of the preoptic area in male mating behaviour. Experientia, 1954, 10 mating.

LARSSON, K., \& ESSBERG, L. Effect of age on the sexual behaviour of the male rat Gerontologia, 1962, 6, 149-152.

KÖNIG, J. F. R., \& KLIPPEL, R. A. The rat brain. Baltimore: Williams \& Wilkins, 1963.

OLDS, J. Effects of hunger and male sex hormone on self-stimulation of the brain. Journal of Comparative \& Physiological Psychology, 1958, 51, 320-324.

SIEGEL, S. Nonparametric statistics for the behavioral sciences. New York: McGraw-Hill, 1956.

van DIS, H., \& LARSSON, K. Induction of sexual arousal in the castrated male rat by intracranial stimulation. Physiology \& Behavior, 1971, 6, 85-86.

VAUGHAN, E., \& FISHER, A. E. Male sexual behavior induced by electrical stimulation. Science, 1962, 137, 758-760. 